\title{
O Mistrzyni i pamięci aktywnej
}

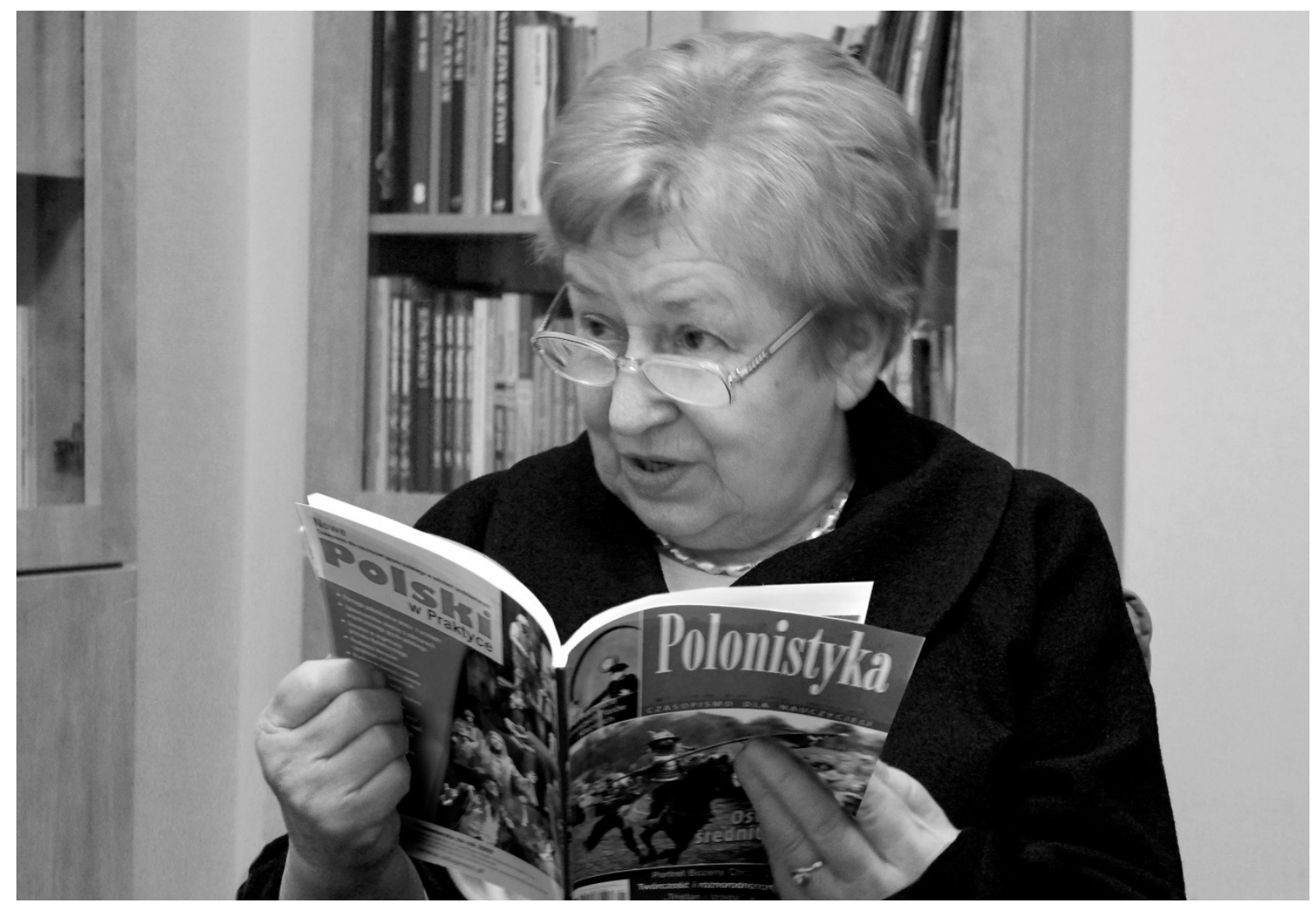

Oddajemy do rąk PT. Czytelników numer wyjątkowo ważny dla naszej redakcji, ale też odmienny niż poprzednie wydania „Polonistyki. Innowacji”. Udostępniamy go prawie dokładnie w pierwszą rocznicę śmierci Profesor Bożeny Chrząstowskiej (zmarła 10 listopada 2020 roku), aby dać świadectwo, jak wiele zawdzięcza jej tak polonistyka szkolna, jak i akademicka. To ona jako charyzmatyczna redaktor naczelna „Polonistyki” sprawiła, że metodyczne pismo stało się ważnym miejscem do wymiany myśli między uniwersytecką teorią a dydaktyczną praktyką. Tę tradycję „Polonistyka. Innowacje” stara się kontynuować, a to upoważnia, ale także obliguje do zastanowienia się nad społecznym znaczeniem humanistyki i edukacji. 
Autorki i autorzy większości artykułów pomieszczonych w numerze nawiązują do licznych książek, podręczników, zagadnień analizowanych przez Bożenę Chrząstowską. Nie są to jednak wypowiedzi ukierunkowane jedynie na przypomnienie czy rekonstrukcję dawnych konstatacji i koncepcji. To raczej próby rozpoznawania zależności między przeszłością a teraźniejszością. Przypominając zasługi twórczyni poznańskiej szkoły dydaktyki, inspirują zarazem do namysłu nad zasadniczymi celami kształcenia humanistycznego.

Każdy z zaproponowanych tematów łączy się z dokonaniami Pani Profesor. Wypowiadają się badaczki i badacze z nią zaprzyjaźnieni, ale i ci, którzy znali ją przede wszystkim z publikacji. Wśród piszących są osoby zajmujące się literaturoznawstwem i takie, którym szczególnie bliskie są kwestie lingwistyczne. Uwaga skupiona jest wokół poezji i języka. Jedna z tez Chrząstowskiej brzmiała przecież: „Najpierw język”. Analizowane są narracje podręcznikowe, komentowane kierunki i mechanizmy wprowadzania interpretacji na lekcjach języka polskiego. Podjęto zagadnienia aksjologiczne i zainicjowana została dyskusja dotycząca jednego z zagadnień biblijnych, tak bliskich naszej Mistrzyni. Zawsze była ona otwarta na współpracę z przedstawicielami różnych dziedzin wiedzy, a przede wszystkim na kontakt ze szkolnymi polonistkami i polonistami. Dlatego publikujemy szkice socjolożki, anglisty oraz projekty nauczycielskie. Są zatem teksty o uczennicach, uczniach, studentkach i studentach nawiązujące do znanego programu Uczę się sam... Jest też recenzja książki wyrastającej ze szkoły Chrząstowskiej.

Zamieściliśmy w numerze bliskie Pani Profesor analizy sztuki słowa i refleksje o sztuce pisania. Nie może w nim zabraknąć też głosu poety:

Józef Baran, Ballada o Słowianach

Prof. Bożenie Chrzastowskiej

wierzchowce nie ujeżdżone

nieokiełznane

słowa słowa słowa

a na słowach słowianie

przez słowa porywani

na oślep na oklep

gdzie serca poniosą

pędzący za obłokami

słowa bez wędzideł

słowa rozbrykane

wielkie większe

koniecznie największe 
słowa które

nie staną się ciałem

lecz liczy się pęd krwi tętent

galopada słów zuchwałych

cóż że zrzucą one w końcu

jeźdźców z Nieba na ziemię

upadkiem karząc

za marzenie

1990

[Z Epifania słoneczna, Poznań 1997, s. 131.]

Wiersz i sformułowana przed nim dedykacja stanowią najlepsze zaproszenie do lektury całości, ale i zachęcają do tego typu refleksji, która otwiera się na przyszłość - do pamięci aktywnej.

Maria Kwiatkowska-Ratajczak 
